\title{
The Reduction of Crude Protein with the Supplementation of Amino Acids in the Diet Reduces the Environmental Impact of Growing Pigs Production Evaluated through Life Cycle Assessment
}

\author{
Lucas A. C. Esteves ${ }^{1, * \mathbb{D}}$, Alessandra N. T. R. Monteiro ${ }^{2} \mathbb{D}$, Natália Y. Sitanaka ${ }^{1}$, Paula C. Oliveira ${ }^{1}$, \\ Leandro D. Castilha ${ }^{1}$, Vinicius R. C. Paula ${ }^{3}$ and Paulo C. Pozza ${ }^{1}$ \\ 1 Department of Animal Science, State University of Maringa, Maringá 87020-900, PR, Brazil; \\ natysitanaka@gmail.com (N.Y.S.); paulacarina.70@gmail.com (P.C.O.); ldcastilha@uem.br (L.D.C.); \\ pcpozza@uem.br (P.C.P.) \\ 2 ANIMINE SAS, 74960 Sillingy, France; rigomonteiroa@gmail.com \\ 3 Department of Animal Science, Luiz de Queiroz College of Agriculture, University of Sao Paulo, \\ Piracicaba 13418-900, SP, Brazil; viniciusrcp@usp.br \\ * Correspondence: lucasantonio_esteves@hotmail.com; Tel.: +55-44-99942-1759
}

Citation: Esteves, L.A.C.; Monteiro, A.N.T.R.; Sitanaka, N.Y.; Oliveira, P.C.; Castilha, L.D.; Paula, V.R.C.; Pozza, P.C. The Reduction of Crude Protein with the Supplementation of Amino Acids in the Diet Reduces the Environmental Impact of Growing Pigs Production Evaluated through Life Cycle Assessment. Sustainability 2021, 13, 4815. https://doi.org/ $10.3390 /$ su13094815

Academic Editor: Ken Byrne

Received: 15 March 2021

Accepted: 20 April 2021

Published: 25 April 2021

Publisher's Note: MDPI stays neutral with regard to jurisdictional claims in published maps and institutional affiliations.

Copyright: (c) 2021 by the authors. Licensee MDPI, Basel, Switzerland. This article is an open access article distributed under the terms and conditions of the Creative Commons Attribution (CC BY) license (https:// creativecommons.org/licenses/by/ $4.0 /)$
Abstract: Two experiments were performed to determine the digestibility of diets with crude protein (CP) reduction supplemented with amino acids (18.15; 17.15; 16.15 and $15.15 \%)$ to growing pigs (30-50 kg), to assess the use of nutrients and account for the manure excretion, and to evaluate the performance, backfat thickness, Longissimus lumborum depth, and plasma urea, aiming to evaluate the environmental impact through life cycle assessment (LCA); for the first time in Brazil interacting experiments were developed to evaluate the $\mathrm{CP}$ reduction and LCA. The CP reduction resulted in greater daily weight gain $(p=0.011)$, final weight $(p=0.020)$, better use of $\mathrm{N}$ and $\mathrm{P}$, through the greater $\mathrm{N}$ and $\mathrm{P}$ retained ( $p=0.003$ and $p=0.017$, respectively). There was a linear reduction in acidification potential $(p=0.015)$, eutrophication potential $(p=0.001)$, and land occupation $(p=0.005)$ when dietary CP decreased from 18.15 to $15.15 \%$. The reduction in CP and supplementation of amino acids in diets for growing pigs (30-50 kg) improved final and daily weight gain. Through LCA, and performance and metabolism data, it was concluded that for the acidification, eutrophication and land occupation categories, impacts were reduced as the protein concentration was reduced.

Keywords: acidification; nitrogen; swine

\section{Introduction}

The quantification of the environmental impact caused by animal production is important because it makes it possible to highlight the critical points of the production process, and, consequently, to guide actions in order to mitigate its effects. Life cycle assessment (LCA) is an effective tool for comparing products and identifying environmental impacts caused by them [1]. In a complex production chain such as pigs, which involves grain production, transportation, feed manufacture, and animal production, among others, LCA allows systemic analysis and identification of critical points of production [2]. In this sense, LCA has already been used to quantify the environmental impact of pig production in several countries, such as Australia [3], Canada [4], Cuba [5], and Italy [6], among others.

Much of the environmental impact caused by pig production occurs during the cultivation period of the ingredients used in the pigs' feed [2,7]. However, due to the large amount of manure generated in the animal production stage and the potential impact on air, water and soil, this stage has been the focus of public discussions. The problem is that manure generated in the production stage, such as nitrogen $(\mathrm{N})$, phosphorus $(\mathrm{P})$ and zinc, can cause acidification, eutrophication and ecotoxicity of the environment. Thus, 
changes in the nutritional composition of the feed can lead to significant differences in the environmental impact caused by the production of pigs, since they will affect the inclusion of ingredients and, consequently, the demand for their production, as well as the digestibility of nutrients such as $\mathrm{N}$ and $\mathrm{P}[7,8]$.

The reduction in crude protein $(\mathrm{CP})$ levels and the supplementation of industrial amino acids in diets provide the best balance between daily requirement of amino acids and daily consumption by the animal. This can provide the best use of some amino acids and, consequently, reduce the excretion of $\mathrm{N}$ [8]. Concomitantly, diets with an adequate balance of amino acids can provide a greater amount of net energy, since when in excess the amino acids cannot be stored, they need to be deaminated, which results in greater energy expenditure by metabolism.

Research aiming to assess the environmental impact of swine production using LCA has already been carried out but is still under development in Brazil. However, efforts have been made to evaluate specific stages of production. To obtain the data for this study, a metabolism experiment was carried out to evaluate the digestibility of nutrients present in the diets, and a second experiment to evaluate the animal performance. Experiments with similar objectives to those proposed in the present study have already been carried out by Reckmann et al. [9] and Monteiro et al. [7]. In the first study, the authors assumed that protein reduction does not influence the performance of animals, since nutritional requirements were met in all diets. In the second study, the digestibility and performance of the animals were evaluated, however, the authors quantified the impacts for much younger animals than those in the current study.

Due to scarce information concerning LCA in Brazil in swine production split into separate phases, the complexity of the digestive and metabolic processes, as well as the difficulty in controlling factors such as the relationship between essential and non-essential amino acids, it is essential that the evaluation of digestibility and the performance of the animals is performed to provide greater precision of the impacts of this production chain. Therefore, the hypothesis of this study was that the reduction of crude protein with the supplementation of amino acids in the diet affects the environmental impact of growing pigs production. The objective of this study was to evaluate the environmental impact, through LCA, of diets with reduction of $\mathrm{CP}$ and supplementation of industrial amino acids for crossbred barrows in the growing phase $(30-50 \mathrm{~kg})$.

\section{Material and Methods}

\subsection{General}

Two experiments (Experiment I and II) were carried out at State University of Maringa, Parana state, Brazil, to perform the LCA. Experiment I was performed in order to determine the digestibility of four diets with protein reduction, to assess the use of nutrients and account for the excretion of manure (feces and urine) in pigs. Experiment II was performed to evaluate the performance, backfat thickness (BT) and Longissimus lumborum muscle depth (LL), and plasma urea of pigs fed the same diets used in Experiment I. All procedures performed in Experiments I and II were approved by the Animal Use Ethics Committee of the State University of Maringa (CEUA $n^{\circ}$ 2846260819).

\subsection{System and Functional Unit Limits}

In order to perform the LCA, the stages of animal production, cultivation, drying and processing of grains, transportation of ingredients to the factory and from the factory to the farm, production of feed, storage, transport and application of manure to the soil were considered. The impacts related to the process of transport and slaughter of the animals were not evaluated, as the impacts were considered at a specific stage (30-50 kg). Furthermore, the slaughter process has a low environmental impact when compared to the stages of feed production and animal production, representing only 1 and $8 \%$ of the total impacts for categories such as acidification potential (AP) and eutrophication potential (EP), respectively [1].

Although the use of the area necessary for the construction of the facilities was not used in the analysis, the area necessary for the production of grains was accounted for in 
the system. The manure generated during the animals' housing phase was accounted for and used as a source of N, $\mathrm{P}$ and potassium - in the fertilization of crops, reducing the use of chemical fertilizers. The equivalence factor (EF) used for $\mathrm{N}$ was $75 \%$, assuming an extra loss of $5 \%$ in the form of nitrate $[10,11]$. For the $\mathrm{P}$ and $\mathrm{K}$ present in the manure, $100 \%$ of the EF was considered [12]. All impacts related to manure management, including storage and application, were allocated and accounted for. The functional unit was one $\mathrm{kg}$ of live weight gain (LWG) in the growing phase (30-50 kg). The definition of the system limits is shown in Figure 1, and was based on Nguyen et al. [11].

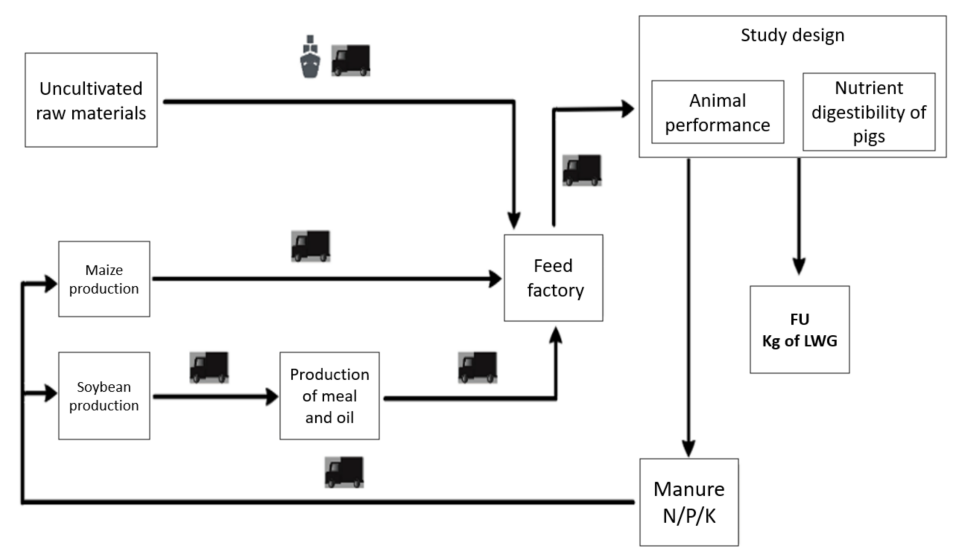

Figure 1. System boundaries of growing pigs' production and study design.

\subsection{Life Cycle Inventory}

The resources used and the emissions associated with the production and transport of raw materials for grain production were obtained through the Ecoinvent software version 3.0 (SimaPro LCA 8.0, Pré Consultants, Amersfoort, The Netherlands). The use of electric energy for lighting and ventilation of the warehouses was considered; however, the emissions and resources used for the construction of the facilities, vaccines, veterinary drugs, detergents and disinfectants used to clean the facilities were not evaluated [13].

\subsection{Grain Production}

It was assumed that the soybeans used were produced in the southern region of Brazil as it is the second largest producer of soybeans, behind only the midwestern region [14]. The inventory for soy cultivation was based on Silva et al. [15], considering an economic allocation to determine the impacts related to oil and soybean meal [10]. The allocation is the partition of environmental impacts between different co-products and can be carried out based on physical characteristics (mass and energy) or other factors such as economic [13]. The inventory for maize cultivation was based on Avarenga et al. [16].

\subsection{Uncultivated Raw Materials}

The inventories for salt, dicalcium phosphate, sodium bicarbonate, limestone and premix were obtained from Wilfart et al. [17]. For the production of antioxidants and growth promoters, the same demand for resources and energy required for the production of premix was considered. For the production of the amino acids L-lysine HCl, DLmethionine and L-threonine, the inventory was obtained through Mosnier et al. [18], which considered the chemical and biological processes in the synthesis of these products. For the production of L-tryptophan, L-valine and L-isoleucine, the demand for resources and energy was twice as high as for the production of L-lysine [10].

\subsection{Transport Specifications}

For the transportation of food and feed, the methodology proposed by Silva et al. [15] was adopted. For the transportation of imported products, transportation was initially established by sea and later by road. Given the importance of the southern region of 
Brazil in pig production, responsible for approximately $69 \%$ of the total number of animals slaughtered in the country [19], grain production was considered in the main producing centers of this region, as well as the region where the farm was located.

\subsection{Feed Formulation and Production}

The treatments evaluated in Experiments I and II consisted of four diets with decreasing levels of $\mathrm{CP}$, as follow: 18.15; 17.15; 16.15 and $15.15 \%$ CP (Table 1). The diets were supplemented with the synthetic amino acids L-lysine, DL-methionine, L-threonine, L-tryptophan, L-valine and L-isoleucine to meet the digestible amino acid requirements for growing pigs (30-50 kg), as proposed by Rostagno et al. [19]. The amino acid composition of corn and soybean meal was determined at Evonik Industries. The digestible amino acids present in food and in the industrial amino acids were calculated using the digestibility coefficients proposed by Rostagno et al. [20]. Sodium bicarbonate was added in the diets to control their electrolyte balance.

Table 1. Ingredients and chemical composition of the experimental diets.

\begin{tabular}{|c|c|c|c|c|}
\hline \multirow{2}{*}{ Ingredients (\%) } & \multicolumn{4}{|c|}{ Crude Protein Content (\%) } \\
\hline & 18.15 & 17.15 & 16.15 & 15.15 \\
\hline Maize & 66.18 & 69.10 & 72.05 & 75.06 \\
\hline Soybean meal & 27.48 & 24.39 & 21.24 & 18.01 \\
\hline Soybean oil & 2.73 & 2.60 & 2.47 & 2.31 \\
\hline Dicalcium phosphate & 1.43 & 1.46 & 1.48 & 1.50 \\
\hline Limestone & 0.70 & 0.713 & 0.725 & 0.737 \\
\hline Sodium bicarbonate & - & 0.155 & 0.314 & 0.475 \\
\hline Salt & 0.460 & 0.343 & 0.236 & 0.127 \\
\hline Vitamin-mineral premix ${ }^{1}$ & 0.400 & 0.400 & 0.400 & 0.400 \\
\hline L-Lysine $\mathrm{HCl} 78.0 \%$ & 0.305 & 0.400 & 0.497 & 0.597 \\
\hline DL-Methionine $99.0 \%$ & 0.115 & 0.142 & 0.170 & 0.199 \\
\hline L-Threonine 98.5\% & 0.128 & 0.170 & 0.213 & 0.258 \\
\hline L-Tryptophan $98.0 \%$ & 0.033 & 0.049 & 0.065 & 0.082 \\
\hline L-Valine $98.0 \%$ & - & 0.034 & 0.088 & 0.143 \\
\hline L-Isoleucine $100.0 \%$ & - & - & 0.011 & 0.066 \\
\hline Antioxidant ${ }^{2}$ & 0.015 & 0.015 & 0.015 & 0.015 \\
\hline Growth promoter ${ }^{3}$ & 0.020 & 0.020 & 0.020 & 0.020 \\
\hline \multicolumn{5}{|l|}{ Calculated composition (\%) } \\
\hline Calcium & 0.722 & 0.722 & 0.722 & 0.722 \\
\hline Available phosphorus & 0.357 & 0.357 & 0.357 & 0.357 \\
\hline Sodium & 0.195 & 0.190 & 0.190 & 0.190 \\
\hline Potassium & 0.715 & 0.668 & 0.619 & 0.570 \\
\hline Chlorine & 0.407 & 0.356 & 0.313 & 0.268 \\
\hline SID lysine & 1.069 & 1.069 & 1.069 & 1.069 \\
\hline SID methionine & 0.357 & 0.370 & 0.385 & 0.399 \\
\hline SID met + cys & 0.631 & 0.631 & 0.631 & 0.631 \\
\hline SID threonine & 0.695 & 0.695 & 0.695 & 0.695 \\
\hline SID tryptophan & 0.214 & 0.214 & 0.214 & 0.214 \\
\hline SID valine & 0.755 & 0.738 & 0.738 & 0.738 \\
\hline SID isoleucine & 0.680 & 0.629 & 0.588 & 0.588 \\
\hline SID histidine & 0.435 & 0.408 & 0.380 & 0.351 \\
\hline SID phenylalanine & 0.796 & 0.741 & 0.686 & 0.629 \\
\hline Metabolizable energy $(\mathrm{kcal} / \mathrm{kg})$ & 3350 & 3350 & 3350 & 3350 \\
\hline
\end{tabular}

${ }^{1}$ Quantity per kg of feed: vitamin A as retinyl acetate, 4000 IU; vitamin D3 as cholecalciferol, 600 IU; vitamin $\mathrm{E}$ as DL-alpha tocopheryl, $12 \mathrm{UI}$; vitamin $\mathrm{K} 3$ as menadione nicotinamide bisulfate, $3 \mathrm{mg}$; thiamin as thiamine mononitrate, $0.6 \mathrm{mg}$; riboflavin, $3.5 \mathrm{mg}$; pyridoxine as pyridoxine hydrochloride, $1 \mathrm{mg}$; vitamin $\mathrm{B} 12,0.018 \mathrm{mg}$; folic acid, $1 \mathrm{mg}$; pantothenic acid as D-calcium pantothenate, $10 \mathrm{mg}$; niacin, $20 \mathrm{mg}$; biotin, $0.03 \mathrm{mg}$; choline chloride, $0.16 \mathrm{~g} ; \mathrm{Fe}, 35 \mathrm{mg}$ as iron sulfate, $\mathrm{Cu}, 15 \mathrm{mg}$ as copper sulfate, $\mathrm{Mn}, 25 \mathrm{mg}$ as manganese monoxide; $\mathrm{Zn}$, $75 \mathrm{mg}$ as zinc sulfate; I, $1 \mathrm{mg}$ as calcium iodate; Se as sodium selenite and selenium yeast, $0.3 \mathrm{mg}$. ${ }^{2}$ Butylated hydroxytoluene; ${ }^{3}$ Leucomycin. 
The amino acids lysine, methionine, threonine, tryptophan, valine, isoleucine, arginine, leucine, phenylalanine and histidine were considered essential amino acids in the calculation of the relationship between essential amino acids: non-essential amino acids. For this calculation, the total concentration of each of these amino acids was considered, as well as the amount of $\mathrm{N}$ present in its composition. The $\mathrm{N}$ values used were those proposed by Rostagno et al. [20]. The $\mathrm{N}$ for the non-essential amino acids was obtained through the difference between the total $\mathrm{N}$ of the diets and the $\mathrm{N}$ present in the essential amino acids, adapted from Toledo et al. [21].

The rations production process data were based on those proposed by GarciaLaunay et al. [10].

\subsection{Experiment I}

Twenty crossbred barrows $(31.80 \pm 2.39 \mathrm{~kg}$ LW) were housed in metabolic cages, distributed in a randomized block design, with four treatments and five replications, one animal per experimental unit (20 units).

The amount of feed provided daily was calculated based on the metabolic LW $\left(\mathrm{LW}^{0.75} \mathrm{~kg}\right)$ and the average consumption recorded during the 7 days adaptation period. In the feeding time, aiming to decrease waste and facilitate ingestion, water was added in the rations in a quantity of $30 \%$ of the total amount of feed provided per meal, which was performed twice a day (7:30 a.m. and 3:30 p.m.). After each meal, water was supplied in the feeder in the proportion of $3 \mathrm{~mL}$ of water per $\mathrm{g}$ of feed, to avoid excessive water consumption.

To determine the period of beginning and ending of the collection of feces, $2 \%$ ferric oxide was added to the diets. The feces were collected daily ( 5 days total) and placed in plastic bags and stored in a freezer $\left(-18{ }^{\circ} \mathrm{C}\right)$. The urine was filtered and collected daily

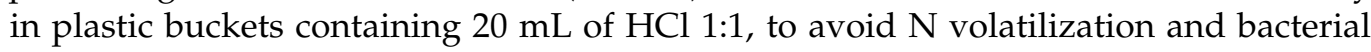
proliferation. Aliquots of $20 \%$ of the total volume were removed and packed in plastic bottles and frozen $\left(-18{ }^{\circ} \mathrm{C}\right)$. At the end of the collection period, feces were mixed by pig, weighed, sampled, dried at $55^{\circ} \mathrm{C}$ for $72 \mathrm{~h}$, and ground through a $1 \mathrm{~mm}$ screen to be analyzed.

\subsection{Experiment II}

Forty-four crossbred barrows $(30.10 \pm 0.63 \mathrm{~kg} \mathrm{LW})$ were distributed in a randomized block design, with four treatments and 11 replications, one animal per experimental unit. The animals were weighed at the beginning and at the end of the experimental period to determine daily weight gain (DWG). The rations provided and leftovers were also weighed to calculate daily feed intake (DFI) and feed conversion rate (FCR).

When the average LW of pigs was $51.21 \pm 2.83 \mathrm{~kg}$, the animals were shaved between the tenth and eleventh ribs [22], and the BT and LL were measured using an ecocamera (Aloka, Inc., SSD-500 Vet, Twinsburg, OH, USA) coupled to a $14.5 \mathrm{~cm}$ and $3.5 \mathrm{MHz}$ probe.

At the end of the experimental period, the animals were fasted for $6 \mathrm{~h}$, and blood samples were collected in tubes containing EDTA, which were centrifuged at $3000 \mathrm{rpm}$ for $15 \mathrm{~min}$. The plasma was transferred to polyethylene microtubes and stored in the freezer $\left(-18^{\circ} \mathrm{C}\right)$. The urea analysis was performed by the colorimetric method, using a commercial kit (Gold Analyzes, Brazil), following its standard operating procedures.

\subsection{Laboratory Analysis}

The diets, feces and urine were analyzed for $\mathrm{N}$ (method 984.13, [23]), and diets and feces for dry matter (method 950.46, [23]), ash (method 942.05, [23]), and crude fiber (method 962.09, [23]). The P (method 965.17, [23]), zinc [24], copper [24], and potassium (method 984.27 [23]) analyses were performed by UV-Vis spectrophotometer. 


\subsection{Life Cycle Impact}

Emissions were calculated for the stages of animal housing, storage and application of manure, according to Monteiro et al. [25]. Through laboratory analysis, the amounts of $\mathrm{N}, \mathrm{P}$ and excreted organic matter were obtained for later determination of the amounts of each nutrient available for application.

The copper, zinc and $\mathrm{K}$ excretion were determined by the equations proposed by Rigolot et al. [26]. The $\mathrm{NH}_{3}$ emissions resulting from the stages of accommodation and manure management were carried out considering the temperature of the shed and were calculated according to Rigolot et al. [27] and the IPCC [28].

The LCA was based on the CML 2001 (baseline) version 3.02, implemented in Simapro version 8.05 (Pré Consultants), adding the following categories: land occupation ( $\mathrm{LO}, \mathrm{m}^{2}$ ) from CML 2001 (all categories) version 2.04 and cumulative energy demand (CED, MJ-eq.) version 1.8 (non-renewable fossil + nuclear).

The characterization factors used to calculate the impact of growing pig production were: global warming potential (GWP, $\mathrm{kg} \mathrm{CO}_{2}$-eq.), $\mathrm{AP}$ (g SO 2 -eq.), $\mathrm{EP}$ (g PO $\mathrm{g}_{4}$-eq.), terrestrial ecotoxicity (TE, g 1,4-DCB-eq.), CED, and LO. For the GWP category, the potential for global warming over a 100-year horizon was considered.

\subsection{Interpretation and Statistical Analysis}

The retention coefficients of $\mathrm{N}$ and $\mathrm{P}$ were obtained for each experimental diet. These coefficients were used to determine the excreted amounts of each element during the growing period, using data from the performance evaluation of the animals. The LCA calculations were evaluated for each animal, and according to the consumption and excretion data of the animals, the environmental profile of each system was constructed using the SAS software version 9.2 (SAS Inst. Inc., Cary, NC, USA).

The performance, excretion and environmental impact data were subjected to analysis of variance using PROC GLM. The treatments and block effects were included in the statistical model. The significant data were submitted to regression analysis. The degrees of freedom related to the $\mathrm{CP}$ levels were divided into polynomials. Treatment differences were considered statistically significant at $p<0.05$ and trends at $p<0.10$. All analyses were performed using SAS software version 9.2 (SAS Inst. Inc., Cary, NC, USA).

\section{Results}

\subsection{Life Cycle Assessment of Feed}

The reduction in $\mathrm{CP}$ increased the environmental impact for the categories evaluated, except for LO (Table 2). The most relevant increase was observed for the categories GWP, $\mathrm{AP}$ and CED. When comparing the differences between the diets with the highest and lowest protein values, the increase observed for the categories mentioned was between 12 and $21 \%$. The exception was in relation to the impact caused to the LO category, which was $7 \%$ lower when the diet went from 18.15 to $15.15 \%$ CP.

Table 2. Life cycle assessment (per kg of feed) in growing pigs (30-50 kg) fed diets with decreasing levels of crude protein and synthetic amino acids supplementation.

\begin{tabular}{ccccc}
\hline \multirow{2}{*}{ Items $^{\mathbf{1}}$} & \multicolumn{4}{c}{ Crude Protein Content (\%) } \\
\cline { 2 - 5 } & $\mathbf{1 8 . 1 5}$ & $\mathbf{1 7 . 1 5}$ & $\mathbf{1 6 . 1 5}$ & $\mathbf{1 5 . 1 5}$ \\
\hline GWP (g CO -eq.) & 410 & 424 & 440 & 461 \\
AP (g SO -eq.) & 10.61 & 11.07 & 11.55 & 12.05 \\
EP (g PO -eq.) & 4.38 & 4.39 & 4.40 & 4.42 \\
CED (MJ-eq.) & 5.37 & 5.66 & 6.02 & 6.50 \\
TE (g 1,4-DCB-eq.) & 4.63 & 4.75 & 4.89 & 5.07 \\
LO (m ${ }^{2}$ year) & 1.11 & 1.08 & 1.06 & 1.03 \\
\hline
\end{tabular}

${ }^{1}$ Global warming potential (GWP); acidification potential (AP); eutrophication potential (EP); cumulative energy demand (CED); terrestrial ecotoxicity (TE); and land occupation (LO). 


\subsection{Metabolism and Performance}

A reduction in the total $\mathrm{N}(p<0.001)$ and $\mathrm{P}(p=0.002)$ excretion was observed in the animals fed the $\mathrm{CP}$ reduced diets (Table 3). The lower excretion was due to the greater retention of these elements. The retained $\mathrm{N}$ increased from 61.48 to $69.93 \%$ in the diets of 18.15 and $15.15 \%$ CP, respectively. Retained P increased from $49.39 \%$ in the diet with the highest protein content to $56.05 \%$ in the diet with the lowest CP level. The reduction in dietary $\mathrm{CP}$ also promoted a lower $\mathrm{N}(p<0.001)$ and $\mathrm{P}(p=0.004)$ intake.

Table 3. Nitrogen and phosphorus balance of growing pigs (30-50 kg) fed diets with decreasing levels of crude protein and synthetic amino acid supplementation (Experiment I).

\begin{tabular}{|c|c|c|c|c|c|c|c|}
\hline \multirow{2}{*}{ Items } & \multicolumn{4}{|c|}{ Crude Protein Content (\%) } & \multirow{2}{*}{ SEM $^{1}$} & \multicolumn{2}{|c|}{$p$-Value } \\
\hline & 18.15 & 17.15 & 16.15 & 15.15 & & Lin. & Quad. \\
\hline $\mathrm{N}$ intake $(\mathrm{g} / \mathrm{d})$ & 42.69 & 40.12 & 38.01 & 35.60 & 0.889 & $<0.001^{2}$ & 0.895 \\
\hline $\mathrm{N}$ in feces $(\mathrm{g} / \mathrm{d})$ & 5.23 & 4.58 & 4.89 & 4.30 & 0.167 & 0.111 & 0.926 \\
\hline $\mathrm{N}$ in urine $(\mathrm{g} / \mathrm{d})$ & 11.27 & 9.49 & 8.53 & 6.47 & 0.514 & $<0.001^{3}$ & 0.655 \\
\hline $\mathrm{N}$ excreted $(\mathrm{g} / \mathrm{d})$ & 16.50 & 14.07 & 13.42 & 10.76 & 0.628 & $<0.001^{4}$ & 0.819 \\
\hline N Retention (\%) & 61.48 & 65.02 & 64.74 & 69.93 & 0.923 & $0.003^{5}$ & 0.479 \\
\hline P intake $(\mathrm{g} / \mathrm{d})$ & 7.96 & 7.56 & 7.41 & 7.38 & 0.139 & $0.004^{6}$ & 0.146 \\
\hline$P$ in feces $(g / d)$ & 4.04 & 3.52 & 3.52 & 3.24 & 0.111 & $0.002^{7}$ & 0.146 \\
\hline P absorbed (\%) & 49.39 & 53.50 & 52.50 & 56.05 & 0.904 & $0.017^{8}$ & 0.857 \\
\hline
\end{tabular}

${ }^{1}$ Standard error of the mean; ${ }^{2}$ Linear effect $\mathrm{y}=-0.425369+2.33066 \times\left(\mathrm{R}^{2}=1.00\right) ;{ }^{3}$ Linear effect $\mathrm{y}=-16.9499$ $+1.52642 \times\left(R^{2}=0.98\right) ;{ }^{4}$ Linear effect $y=-16.1960+1.76183 \times\left(R^{2}=0.96\right) ;{ }^{5}$ Linear effect $y=106.973-2.45713$ $\mathrm{x}\left(\mathrm{R}^{2}=0.86\right) ;{ }^{6}$ Linear effect $\mathrm{y}=4.41227+0.186837 \times\left(\mathrm{R}^{2}=0.83\right) ;{ }^{7}$ Linear effect $\mathrm{y}=-0.365033+0.232662 \mathrm{x}$ $\left(\mathrm{R}^{2}=0.86\right) ;{ }^{8}$ Linear effect $\mathrm{y}=83.8951-1.8295 \times\left(\mathrm{R}^{2}=0.79\right)$.

Despite the lower intake of $\mathrm{N}$ and $\mathrm{P}$ by the pigs fed the lower $\mathrm{CP}$ levels diets, no differences were observed for the FCR, DFI, and LL $(p>0.05)$, and a trend was observed in BT and plasma urea $(p<0.10)$ (Table 4). However, there was an increase in the final weight $(p=0.020)$ and in the DWG $(p=0.011)$ with the reduction of CP in the diet. An increase of $11 \%$ in the DWG was observed, comparing the highest $(1.034 \mathrm{~kg})$ and the lowest $(1.150 \mathrm{~kg})$ levels of $\mathrm{CP}$ in the diets.

Table 4. Performance, body and biochemical parameters of growing pigs (30-50 kg) fed diets with decreasing levels of crude protein and synthetic amino acid supplementation (Experiment II).

\begin{tabular}{|c|c|c|c|c|c|c|c|}
\hline \multirow{2}{*}{ Items $^{1}$} & \multicolumn{4}{|c|}{ Crude Protein Content (\%) } & \multirow{2}{*}{ SEM $^{2}$} & \multicolumn{2}{|c|}{$p$-Value } \\
\hline & 18.15 & 17.15 & 16.15 & 15.15 & & Lin. & Quad. \\
\hline Final weight (kg) & 49.84 & 50.25 & 52.65 & 52.12 & 0.426 & $0.020^{3}$ & 0.578 \\
\hline DWG (kg) & 1.034 & 1.045 & 1.184 & 1.150 & 0.029 & $0.011^{4}$ & 0.594 \\
\hline FCR $(\mathrm{kg})$ & 1.933 & 1.879 & 1.851 & 1.840 & 0.022 & 0.133 & 0.634 \\
\hline DFI (kg) & 1.991 & 1.967 & 2.185 & 2.105 & 0.039 & 0.128 & 0.717 \\
\hline $\mathrm{BT}(\mathrm{cm})$ & 0.56 & 0.59 & 0.67 & 0.67 & 0.028 & 0.062 & 0.718 \\
\hline $\mathrm{LL}(\mathrm{cm})$ & 3.80 & 3.82 & 3.68 & 4.00 & 0.079 & 0.459 & 0.294 \\
\hline Urea (mg/dL) & 28.38 & 22.75 & 18.40 & 22.58 & 1.557 & 0.085 & 0.083 \\
\hline
\end{tabular}

${ }^{1}$ Daily weight gain (DWG); feed conversion rate (FCR); daily feed intake (DFI); backfat thickness (BT); Longissimus lumborum muscle depth (LL); ${ }^{2}$ Standard error of the mean ${ }^{3}$ Linear effect $y=67.2979-0.948293 x$ $\left(R^{2}=0.75\right),{ }^{4}$ Linear effect $y=1.96421-0.0507608 \times\left(R^{2}=0.71\right)$.

\subsection{Life Cycle Analysis of Growing Pigs Production}

Although there was an increase for the impact categories evaluated in the feed production stage when $\mathrm{CP}$ was reduced in diets, with the exception of the LO category, this behavior was not observed in relation to animal production (Table 5). Crude protein reduction resulted in less impact on the AP $(p=0.015), \mathrm{EP}(p=0.001)$ and LO $(p=0.005)$ categories, with no difference $(p>0.05)$ on the GWP, CED and TE categories. The animals that received the $15.15 \% \mathrm{CP}$ diet reduced by 11,13 and $12 \%$ the impacts for categories $\mathrm{AP}$, 
EP and LO, respectively, when compared to the animals that received the diet with the highest crude protein level. The relative contribution of feed production, animal housing and manure management of the low protein (a) and high protein system by categories is showed in Figure $2 \mathrm{a}, \mathrm{b}$.

Table 5. Potential environmental impacts (per $\mathrm{kg}$ of live weight) of growing pigs ( $30-50 \mathrm{~kg}$ ) fed diets with decreasing levels of crude protein and synthetic amino acid supplementation.

\begin{tabular}{|c|c|c|c|c|c|c|c|}
\hline \multirow{2}{*}{ Items $^{1}$} & \multicolumn{4}{|c|}{ Crude Protein Content (\%) } & \multirow{2}{*}{ SEM $^{2}$} & \multicolumn{2}{|c|}{$p$-Value } \\
\hline & 18.15 & 17.15 & 16.15 & 15.15 & & & Lin. \\
\hline GWP (g CO 2 -eq.) & 2.95 & 2.87 & 2.82 & 2.80 & 0.033 & 0.398 & - \\
\hline $\mathrm{AP}$ (g SO 2 -eq.) & 35.34 & 34.25 & 33.18 & 31.58 & 0.442 & 0.015 & 0.002 \\
\hline $\mathrm{EP}\left(\mathrm{g} \mathrm{PO}_{4}\right.$-eq. $)$ & 11.90 & 11.36 & 10.87 & 10.31 & 0.156 & 0.001 & $<0.001$ \\
\hline CED (MJ-eq.) & 17.35 & 17.44 & 17.22 & 18.36 & 0.214 & 0.224 & - \\
\hline TE (g 1,4-DCB-eq.) & 11.89 & 11.09 & 11.58 & 11.69 & 0.144 & 0.253 & - \\
\hline $\mathrm{LO}\left(\mathrm{m}^{2}\right.$ year $)$ & 2.15 & 2.03 & 1.96 & 1.89 & 0.027 & 0.005 & $<0.001$ \\
\hline
\end{tabular}

${ }^{1}$ Global warming potential (GWP); acidification potential (AP); eutrophication potential (EP); cumulative energy demand (CED); terrestrial ecotoxicity (TE); and land occupation (LO). ${ }^{2}$ Standard error of the mean.

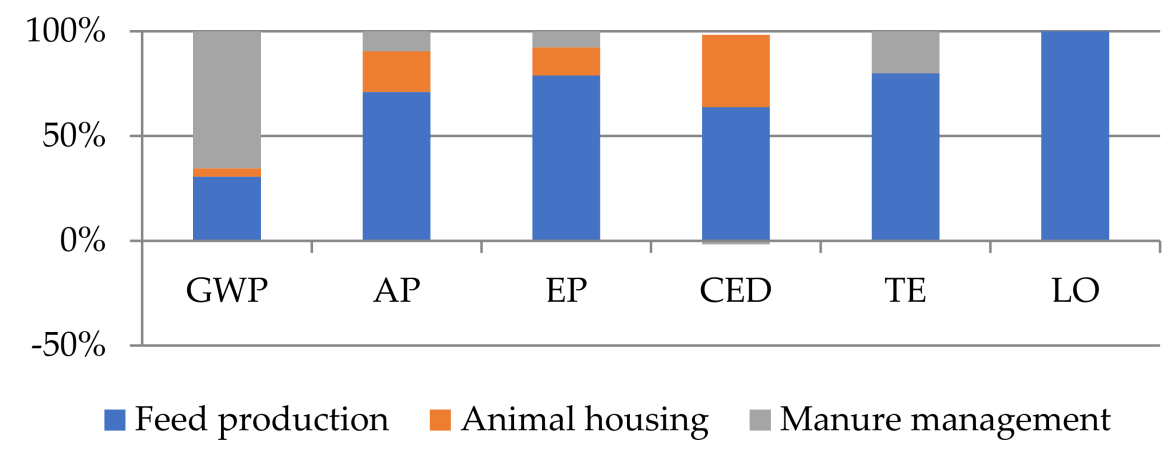

(a)

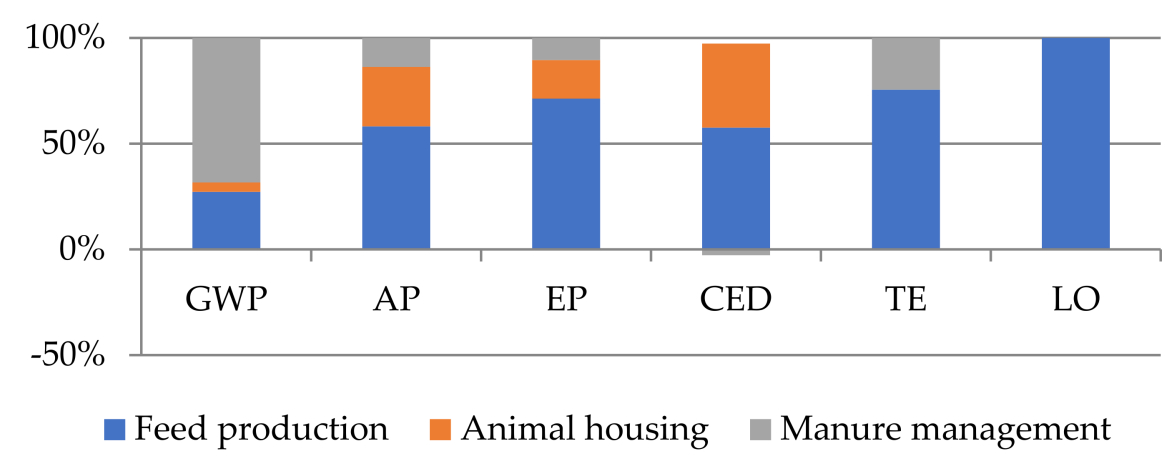

(b)

Figure 2. Relative contributions of feed production, animal housing and manure management of the low protein (a) and high protein (b) system to the categories global warming potential (GWP), acidification potential (AP), eutrophication potential (EP), cumulative energy demand (CED), terrestrial ecotoxicity (TE) and land occupation (LO).

\section{Discussion}

The greatest impact on the categories AP and EP obtained for diets with a lower protein level was also observed in another study. Assessing the impact of different diets on growing pigs, Reckmann et al. [9] observed an increase of 7 and $4 \%$ in the environmental 
impact for the categories AP and EP, respectively, comparing a conventional diet with a diet with greater inclusion of industrial amino acids and a lower protein level. The smallest difference in AP between the diets with the highest and lowest protein levels observed by the aforementioned authors and in the present study may have occurred due to the ingredients used in the formulation of the diets. In this study, the diets were corn-soybean meal based, and Reckmann et al. [9] used wheat, barley and soybean meal as the major ingredients in their diets. Wheat and barley have more than double the neutral detergent fiber content than corn [20], and dietary fiber is associated with decreased utilization of nutrients such as protein and low net energy value [29]. Protein reduction may also be one of the reasons for this variation; however, the aforementioned authors described a similar reduction in $\mathrm{CP}$ between the diets with the highest and lowest protein levels compared to the current study (15 and 16\%, respectively).

The higher excretion of $\mathrm{N}$ for animals fed the high levels of $\mathrm{CP}$ diets was also observed by Monteiro et al. [7], who found total excretion of $\mathrm{N}$ varying from 8.22 to $5.84 \mathrm{~g} / \mathrm{d}$ in diets with 19 and 16\% CP, respectively. However, these authors evaluated the protein reduction for lighter pigs (15 to $30 \mathrm{~kg}$ ). This reduction in $\mathrm{N}$ excretion was $29 \%$, whereas the reduction observed in the present study was 35\%. The retention and excretion of $\mathrm{N}$ corroborate other studies that aimed to assess the impact of reducing CP for pigs $[8,21,30]$. The lower $\mathrm{N}$ excretion may have occurred due to the improved utilization of the dietary amino acids in diets with protein reduction supplemented with industrial amino acids. Because acidification is an environmental problem caused by anthropogenic air pollutants that have $\mathrm{N}$ in their composition, such as $\mathrm{NH}_{3}$ and $\mathrm{NOx}$ [31], this corroborated the finding concerning reduced AP in the lowest CP levels in the present study. He et al. [8] concluded that there are differences in the ileal digestibility of amino acids such as lysine, methionine, threonine, tryptophan, and valine when the CP level of diet for growing pigs was reduced from 18 to $13 \%$. In the same study, the authors highlighted that the ileal digestibility of lysine increased from 72 to $80 \%$ compared to diets with higher and lower protein levels, respectively [8].

The best DWG observed in the animals that received diets with a lower protein level may be a consequence of the meeting of the daily requirement of most essential amino acids achieved by the synthetic amino acid supplementation. The failure to meet the requirements of some of these amino acids would result in reduced performance. On the other hand, a reduction in the DWG of the pigs fed the lower CP level diets was observed by $\mathrm{He}$ et al. [8]. However, the authors did not add valine, isoleucine and other amino acids to the diets, which may have compromised the animals' performance when they were deficient in the diets.

The feed intake is another parameter that corroborated the belief that amino acid requirements were met, as there were no differences in DFI and FCR. Providing a lower lysine concentration diet to pigs fed ad libitum, Schiavon et al. [32] observed that the animals were able to self-regulate the dietary deficiency of this amino acid by increasing the feed intake, concluding that amino acid restriction can lead to increased feed intake.

Protein consumption above the requirements of pigs generally results in the highest concentration of urea in the blood plasma, due to the greater deamination of amino acids that exceed the animal's daily requirement. Remus et al. [33] reported that higher protein utilization efficiency, obtained through precision feeding and, consequently, lower protein consumption, reduces the plasma urea concentration of growing pigs. On the other hand, Pasquetti et al. [34] pointed out that an amino acid deficiency can also limit protein synthesis and increase deamination.

The tendency to increase BT and to reduce plasma urea observed in this study as the levels of $\mathrm{CP}$ in the diets were reduced was in accordance with the results observed in the metabolism experiment. The lower $\mathrm{N}$ excretion corroborated these results, due to the lower energy expenditure required in deamination of excess amino acids. The results obtained are in agreement with those of Schiavon et al. [32], who observed higher $\mathrm{N}$ consumption 
and excretion by pigs fed diets with a higher protein concentration, and also highlight that the protein reduction provided an increase in intramuscular fat in the LL.

The better use of $\mathrm{N}$, increasing the relationship between essential amino acids-nonessential amino acids in the diets, corroborated the results obtained by Lenis and Jongbloed [35], who observed a better $\mathrm{N}$ use when the diet presented the relation between essential amino acids-non-essential amino acids from 38:62 to 50:50. However, the authors also emphasized that this relation between essential amino acids-non-essential amino acids is more important when there is a reduction in total $\mathrm{N}$ of the diet.

For the GWP category, the results varied between 2.95 and $2.80 \mathrm{~kg} \mathrm{CO}_{2}$-eq. of LWG, higher than those reported by Monteiro et al. [7], which can be related to the worsening in feed conversion and the higher excretion of $\mathrm{N}$ in the current study. Higher results for this category were obtained by Bandekar et al. [36]; however, besides using dried distiller grains with solubles as the main protein source in the diets, the authors showed results for the LCA in different stages of creation (gestation, lactation, growing and finishing), in addition to different managements performed in each phase, such as comparison between sows managed in cages or in groups, diets without the use of growth promoters, immunocastrated or surgically castrated animals and evaluation of the use of ractopamine.

In this context, Bandekar et al. [36] reported that management that results in a reduction in the DWG can provide an increase in the emission of greenhouse gases because the lower the DWG, the longer the animal takes to reach the slaughter weight, which provides the highest feed consumption and higher production of manure. As in this study, the authors observed that the stages of manure management and food production were the ones that most contributed to GWP.

Although the greater inclusion of amino acids increased AP when considering the $\mathrm{kg}$ of feed produced, this result was not observed when considering the impact on animal production, in view of the impact obtained for the highest dietary $\mathrm{CP}$ was $35.34 \mathrm{~g} \mathrm{SO}_{2}$-eq. per $\mathrm{kg}$ of LWG. However, for the diet with greater inclusion of amino acids the value obtained was $31.58 \mathrm{~g} \mathrm{SO}_{2}$-eq. per $\mathrm{kg}$ of LWG. According to Reckmann et al. [9], the inclusion of industrial amino acids in diets of the animals is an efficient way to reduce the environmental impact of pig production. It was possible to reduce the impacts between 3 and $11 \%$ for GWP, AP, EP and LO, when compared to the results of a conventional diet [9].

The inclusion of industrial amino acids in diets is of great importance for AP, and as confirmed by the metabolism trial (Experiment I), the lower protein concentration resulted in better utilization of $\mathrm{N}$ present in the diet, and consequently, provided less $\mathrm{N}$ excretion to the environment ( $36 \%$ less than the $18.15 \% \mathrm{CP}$ diet). Comparing both experiments (metabolism and performance), it was possible to observe a reduction of $29 \%$ in the total $\mathrm{N}$ emission during the process of animal housing and manure management between the diets with higher and lower protein levels. This value was close to the estimated in relation to the emission of $\mathrm{NH}_{3}$, in view of the reduction of $29 \%$ in the emission of this gas by the lowest protein concentration diet.

$\mathrm{NH}_{3}$ is a relevant gas to the process of environmental acidification, and although the production of feed has been responsible for most of the impact in the AP category, the animal housing and manure management stage have relevant impacts for this category, precisely by the $\mathrm{NH}_{3}$ emission [1,37]. The lower excretion of $\mathrm{N}$ obtained for animals fed diets with the lower protein level may explain the significant reduction in the impact for AP.

For the EP category a reduction was observed from 11 to $10 \mathrm{~g} \mathrm{PO}_{4}$-eq. per $\mathrm{kg}$ of LWG, for the pigs fed the 18.15 and $15.15 \% \mathrm{CP}$ diets, respectively. As for AP, $\mathrm{N}$ is also responsible for causing the EP to environments. Another element that can cause eutrophication of the environment is $\mathrm{P}$ [38]. The protein reduction resulted in greater digestibility of the $\mathrm{P}$ present in the diet, and this may have occurred due to the lower concentration of phytic $\mathrm{P}$ in the diets of lower protein value.

The lower inclusion of soybean meal provided a reduction in the concentration of phytic $\mathrm{P}$ because soybean meal has a greater amount of phytic $\mathrm{P}(0.36 \%)$ in its composition in relation to the amount present in corn $(0.18 \%)$ [20]. Thus, the $15.15 \% \mathrm{CP}$ diet has $8 \%$ less 
phytic $\mathrm{P}$ when compared to the $18.15 \% \mathrm{CP}$ diet. The lower excretion of $\mathrm{P}$ and $\mathrm{N}$ caused less environmental impact per $\mathrm{kg}$ of LWG, even with the observed increase for the EP in relation to production per $\mathrm{kg}$ of feed.

The lower impact for the AP and EP categories, due to the protein reduction in the pigs' diet, has already been reported in other studies [25,39]. However, Monteiro et al. [7] did not observe differences for these categories when assessing protein reduction for younger pigs, which may be due to the animals presenting the same performance between the evaluated diets. On the other hand, in the present study the reduction in $\mathrm{CP}$ in the diet provided improvement in the animals' weight gain. This better weight gain may be related to the higher net energy of diets with reduced protein. Weight gain combined with better use of nutrients can be one of the reasons for the reductions observed in relation to AP and EP.

There was no difference in the CED according to the $\mathrm{CP}$ levels evaluated and, as well as for AP, EP, TE and LO; feed production is the stage that most contributed to the impact of this category. Feed production represents $63 \%$ of the impacts observed for the CED category. The production of synthetic amino acids requires a large amount of energy [18], thus, the inclusion of these amino acids in the diets caused an increase in CED for the production of diets with lower CP. In the evaluation of LCA related to animal production per $\mathrm{kg}$ of LWG, it was possible to observe that the feed production process had a greater contribution in the feed of $15.15 \% \mathrm{CP}$ in relation to the $18.15 \% \mathrm{CP}$, due to the higher energy demand in the production of amino acids.

Although there was a difference of greater amplitude in relation to CED of the evaluated diets (per $\mathrm{kg}$ of feed), the same pattern was not observed in relation to animal production, which can be attributed to the greater DWG of the animals that received the diets with lower concentration of CP. The high contribution of feed production to CED was also observed in other studies [2,3,7,13]. According to Weidemann et al. [3], feed production had a significant contribution in relation to energy demand. The authors observed a variation in the contribution of this stage from 59 to $72 \%$ between the evaluated systems.

In order to assess the impact of pig production in Argentina, Arrieta and González [13] reported that the high energy demand was attributed to the production of food used in the production of feed, with the production of fertilizers representing $35 \%$ of this expenditure. One way to mitigate the energy demand is through the use of manure as fertilizers, and in this study, it was considered that part of the soil fertilization could be carried out through the available manure, thus it is possible to observe that the manure management has a negative effect on the CED.

As the area required for the construction of the LCA facilities was not considered in this study, most of the impact related to the LO category was attributed to the grain production. Thus, it was possible to observe that the reduction of $\mathrm{CP}$ in the diet provided a reduction in the impact for the $\mathrm{LO}$ category, regarding both the production of one $\mathrm{kg}$ of feed and the impact on this category for one kg of LWG.

The reduction in impact with the lower inclusion of soybean meal occurred due to the larger area needed for soybean production in relation to the area needed for corn production. A similar result was reported by Garcia-Launay et al. [10], who observed an increase of $19 \%$ in the area required for the production of soybean meal compared to that required for the production of corn, and the same trend was also observed by Monsier et al. [18].

For the production of feed, the difference observed between the treatments of lower and higher protein values for $\mathrm{LO}$ was $7 \%$, from the data obtained for the LCA. Regarding the impact observed on animal performance (one $\mathrm{kg}$ of LWG) the results were 2.15 and $1.89 \mathrm{~m}^{2}$ year, a difference of $12 \%$. As the production of the feeds represented practically the totality of the impacts observed for this category, it was concluded that the biggest difference found in the LCA referring to animal production was due to the greater performance observed for the animals fed the reduced CP diets.

The assessment of the environmental impact in the swine production chain is complex because the elements that can cause environmental problems, such as fertilizer production, food cultivation, transport, feed production, animal production, manure management, and 
processing, among others, are emitted in different stages of the production chain. Changes that aim to reduce the emission of some pollutants must be evaluated in a systemic way, since the possibility to improve some stages of production may result in decreased values in the others. Every change must be discussed and evaluated before being implemented, so that the change in a part of the population does not result in a bigger concern for the entire pig production chain.

\section{Conclusions}

The evaluation of the LCA in this study was determined for 30-50 kg pigs, and it generated data for this specific phase considering the animal performance, the digestibility of diets with levels of crude protein and supplementation of synthetic amino acids. The reduction of crude protein and supplementation of industrial amino acids in diets improved the DWG and final weight of the animals. Concomitantly, the reduced crude protein diets promoted less nitrogen and phosphorus excretion. Through life cycle assessment, and performance and metabolism data, it was concluded that for the acidification, eutrophication and land occupation categories, impacts were reduced as the protein concentration was also reduced. This data may be used in future studies of LCA evaluations, regarding the greater characterization of the system production. New studies can be done on the other production phases for a complete overview of the LCA of swine production.

Author Contributions: L.A.C.E., P.C.P. and A.N.T.R.M. designed this experiment. L.A.C.E., N.Y.S. and P.C.O. developed the animal experiment and collected the data. L.A.C.E., P.C.P., L.D.C. and A.N.T.R.M. participated in result tabulation and statistics. L.A.C.E. and P.C.P. wrote the paper. L.A.C.E. and V.R.C.P. reviewed and edited the writing. L.A.C.E. and P.C.P. supervised all processes through performing the experiment to writing the paper. All authors have read and agreed to the published version of the manuscript.

Funding: The Coordenação de Aperfeiçoamento de Pessoal de Nível Superior (Brasília, Brazil) and Conselho Nacional de Desenvolvimento Científico e Tecnológico for the scholarship to the first author, and to the other graduate student co-authors.

Institutional Review Board Statement: This experiment was approved by the Ethic Committee on Animal Use of the State University of Maringá (CEUA/UEM), protocol number CEUA 2846260819.

Informed Consent Statement: Not applicable.

Data Availability Statement: Data presented in this study are available on request from the corresponding author.

Conflicts of Interest: The authors declare no conflict of interest. The funders had no role in the design of the study; in the collection, analyses, or interpretation of data; in the writing of the manuscript, or in the decision to publish the results.

\section{References}

1. Reckmann, K.; Traulsen, I.; Krieter, J. Life cycle assessment of pork production: A data inventory for the case of Germany. Livest. Sci. 2013, 157, 586-596. [CrossRef]

2. Dourmad, J.Y.; Ryschawy, J.; Trousson, T.; Bonneau, M.; Gonzàlez, J.; Houwers, H.W.J.; Hviid, M.; Zimmer, C.; Nguyen, T.L.T.; Mongesen, L. Evaluating environmental impacts of constracting pig farming systems with life cycle assessment. Animal 2014, 8, 2027-2037. [CrossRef] [PubMed]

3. Weidemann, S.G.; McGahan, E.J.; Murphy, M. Environmental impacts and resource use from Australian pork production determined using life cycle assessment. 2. Energy, water and land occupation. Anim. Prod. Sci. 2018, 58, 1153-1163. [CrossRef]

4. Mackenzie, S.G.; Leinonen, I.; Ferguson, N.; Kyriazakis, I. Can the environmental impact f pig systems be reduced by utilizing co-products as feed? J. Clean. Prod. 2016, 115, 172-181. [CrossRef]

5. $\quad$ Reyes, Y.A.; Barrera, E.L.; Valle, A.S.; Gil, M.P.; García, O.H.; Dewulf, J. Life cycle assessment for the Cuban pig production: Case study in Sancti Spiritus. J. Clean. Prod. 2019, 219, 99-109. [CrossRef]

6. Bava, L.; Zucali, M.; Sandrucci, A.; Tamburini, A. Environmental impact of the typical heavy pig production in Italy. J. Clean. Prod. 2017, 140, 685-691. [CrossRef]

7. Monteiro, A.N.T.R.; Dourmad, J.Y.; Fachinello, M.R.; Diaz-Huepa, L.M.; Sitanaka, N.Y.; Sturzenegger, A.V.; Pozza, P.C. Effect of observed individual data of performance and excretion on life cycle assessment of piglets. Sci. Agric. 2019, 76, 102-111. [CrossRef] 
8. He, L.; Wu, L.; Xu, Z.; Li, T.; Yao, K.; Cui, Z.; Yin, Y.; Wu, G. Low-protein diets affect ileal amino acid digestibility and gene expression of digestive enzymes in growing and finishing pigs. Amino Acids 2016, 48, 21-30. [CrossRef]

9. Reckmann, K.; Blank, R.; Traulsen, I.; Krieter, J. Comparative life cycle assessment (LCA) of pork using different protein sources in pig feed. Arch. Anim. Breed. 2016, 59, 27-36. [CrossRef]

10. Garcia-Launay, F.; Van der Werf, H.M.G.; Nguyen, T.T.H.; Le Tutour, I.; Dourmad, J.Y. Evaluation of the environmental implications of the incorporation on feed-use amino acids in pig production using life cycle assessment. Livest. Sci. 2014, 161, 158-175. [CrossRef]

11. Nguyen, T.L.T.; Hermansen, J.E.; Mongensen, L. Fossil energy and GHG saving potentials of pig farming in the EU. Energy Policy 2010, 38, 2561-2571. [CrossRef]

12. Sommer, S.G.; Maahn, M.; Poulsen, H.D.; Hjorth, M.; Sehested, J. Interactions between phosphorus feeding strategies for pigs and dairy cows and separation efficiency of slurry. Environ. Technol. 2008, 29, 75-80. [CrossRef]

13. Arrieta, E.Z.; González, A.D. Energy and carbono footprints of chicken and pork from intensive production systems in Argentina. Sci. Total Environ. 2019, 673, 20-28. [CrossRef]

14. Conab; Companhia Nacional de Abastecimento. Acompanhamento da Safra Brasileira: Café. Monit. Agric. Safra 2017, 4, 1-98 Available online: http:/ / www.conab.gov.br (accessed on 10 August 2019).

15. Silva, V.P.; Van der Werf, H.M.G.; Spies, A.; Soares, S.R. Variability in environmental impacts of Brazilian soybean according to crop production and transport scenarios. J. Environ. Manag. 2010, 91, 1831-1839. [CrossRef]

16. Avarenga, R.A.F.; Silva Jr, V.P.; Soares, S.R. Comparison of the ecological footprint and a life cycle impact assessment method for a case study on Brazilian broiler feed production. J. Clean. Prod. 2012, 28, 25-32. [CrossRef]

17. Wilfart, A.S.; Espagnol, S.; Dauguet, A.; Tailleur, A.; Gac, A.; Garcia-Launay, F. ECOALIM: A dataset of environmental impacts of feed ingredients used in animal production. PLoS ONE 2016, 11, e0167343. [CrossRef]

18. Mosnier, E.; Van der Werf, H.M.G.; Boissy, J.; Dourmad, J.Y. Evaluation of the environmental implications of the incorporation of feed-use amino acids in the manufacturing of pig and broiler feeds using life cycle assessment. Animal 2011, 5, 1972-1983. [CrossRef]

19. ABPA Relatorio anual da Associação Brasileira de Proteina Animal. 2018. Available online: http://abpa-br.com.br/storage/files/ relatorio-anual-2018.pdf (accessed on 26 September 2019).

20. Rostagno, H.S.; Albino, L.F.T.; Hannas, M.I.; Donzele, J.L.; Sakomura, N.K.; Perazzo, F.G.; Saraiva, A.; Teixeira, M.L.; Rodrigues, P.B.; Oliveira, R.F.; et al. Tabelas Brasileiras Para Aves e Suinos: Composição de Alimentos e Exigências Nutricionais, 4th ed.; UFV: Viçosa, Brazil, 2017; 488p.

21. Toledo, J.B.; Furlan, A.C.; Pozza, P.C.; Carraro, J.; Moresco, G.; Ferreira, S.L.; Gallego, A.G. Reduction of the crude protein content of diets supplemented with essential amino acids for piglets weighing 15 to 30 kilograms. R. Bras. Zootec. 2014, 43, 301-309. [CrossRef]

22. Dutra Jr, W.M.; Ferreira, A.S.; Tarouco, J.U.; Euclydes, R.F.; Donzele, J.L.; Lopes, O.S.; Cardoso, L.L. Estimativas de rendimentos de cortes comerciais e de tecidos de suínos em diferentes pesos de abate ela técnica de ultra-sonografia em tempo real. $R$. Bras. Zootec. 2001, 30, 1243-1250. [CrossRef]

23. Association of Official Analytical Chemists-International. Official Methods of Analysis, 18th ed.; AOAC: Gaithesburg, MD, USA, 2005.

24. Nogueira, A.R.A.; Missaglia, A.P.; Zani, A.; Pellegrino, A.N.; Caputi, B.; Souza, G.B.; Olivares, I.R.B.; Palhares, J.C.P.; Duarte, K.F.; Vieira, O.V.; et al. Compêndio Brasileiro de Alimentação Animal; Ed. Sindicato Nacional da Indústria de Alimentação Animal-Sindirações: Sao Paulo, Brazil, 2017; pp. 1-477.

25. Monteiro, A.N.T.R.; Garcia-Launay, F.; Brossard, L.; Wilfart, A.; Dourmad, J.Y. Effect of feeding strategy on environmental impacts of pig fattening in different contexts of production: Evaluation through life cycle assessment. J. Anim. Sci. 2016, 94, $4832-4847$. [CrossRef]

26. Rigolot, C.; Espagnol, S.; Pomar, C.; Dourmad, J.Y. Modelling of manure production by pigs and $\mathrm{NH}_{3}, \mathrm{~N}_{2} \mathrm{O}_{\text {and }} \mathrm{CH}_{4}$ emissions Part I: Animal excretion and enteric CH4, effect of feeding and performance. Animal 2010, 4, 1401-1412. [CrossRef] [PubMed]

27. Rigolot, C.; Espagnol, S.; Robin, P.; Hassouna, M.; Béline, F.; Paillat, J.M.; Dourmad, J.Y. Modelling of manure production by pigs and $\mathrm{NH}_{3}, \mathrm{~N}_{2} \mathrm{O}$ and $\mathrm{CH}_{4}$ emissions. Part II. Effect of animal housing, manure storage and treatment practices. Animal 2010, 4, 1413-1424. [CrossRef] [PubMed]

28. IPCC Guidelines for National Greenhouse Gas Inventories: Emissions from Livestock and Manure Management. 2006. Available online: http:/ / www.ipcc-nggip.iges.or.jp/public/2006gl/pdf/4_Volume4/V4_10_Ch10_Livestock.pdf (accessed on 15 November 2018).

29. Le Gall, M.; Warpechowski, M.; Jaguelin-Peyraud, Y.; Noblet, J. Influence of dietary fibre level and pelleting on the digestibility of energy and nutrients in growing pigs and adult sows. Animal 2009, 3, 352-359. [CrossRef] [PubMed]

30. Ferreira, R.A.; Oliveira, R.F.M.; Donzele, J.L.; Araújo, C.V.; Silva, F.C.O.; Fontes, D.O.; Saraiva, E.P. Redução do nível de proteína bruta e suplementação de aminoácidos em rações para suínos machos castrados mantidos em ambiente termoneutro dos 30 aos 60 kg. R. Bras. Zootec. 2005, 34, 548-556. [CrossRef]

31. Kim, T.H.; Chae, C.U. Environmental impact analysis of acidification and eutrophication due to emissions from the production of concrete. Sustainability 2016, 8, 578. [CrossRef]

32. Schiavon, S.; Dalla Bona, M.; Carcò, G.; Carraro, L.; Bunger, L.; Gallo, L. Effects of feed allowance and indispensable amino acid reduction on feed intake, growth performance and carcass characteristics of growing pigs. PLoS ONE 2018, 13, e0195645. [CrossRef] 
33. Remus, A.; Pomar, C.; Perondi, D.; Gobi, J.P.; Silva, W.C.; Souza, L.J.; Hauschild, L. Response to dietary methionine supply of growing pigs fed daily tailored diets or fed according to a conventional phase feeding system. Livest. Sci. 2019, 222, 7-13. [CrossRef]

34. Pasquetti, T.J.; Pozza, P.C.; Moreira, I.; Santos, T.C.; Diaz-Huepa, L.M.; Castilha, L.D.; Perondi, D.; Carvalho, P.L.O.; Kim, S.W. Simultaneous determination of stardardized ileal digestible tryptophan and lysine for barrows from 15 to $30 \mathrm{~kg}$ live weight. Livest. Sci. 2015, 181, 114-120. [CrossRef]

35. Lenis, N.P.; Jongbloed, A.W. New technologies in low pollution swine diets: Diet manipulation and use of synthetic amino acids, phytase and phase feeding for reduction of nitrogen and phosphorus excretion and ammonia emission-Review. Asian Australas. J. Anim. Sci. 1999, 12, 305-327. [CrossRef]

36. Bandekar, P.A.; Leh, M.; Bautista, R.; Matlock, M.D.; Thoma, G.; Ulrich, R. Life cycle assessment of alternative swine management practices. J. Anim. Sci. 2019, 979, 472-484. [CrossRef]

37. Basset-Mens, C.; Van der Werf, H.M.G. Scenario-based environmental assessment of farming systems: The case of pig production in France. Agric. Ecosyst. Environ. 2005, 105, 127-144. [CrossRef]

38. Guinée, J.; de Bruijn, H.; van Duin, R.; Huijbregts, M.A.J. Handbook on Life Cycle Assessment: Operational Guide to the ISO Standards, 2nd ed.; Guinée, J., Ed.; Springer: Leiden, The Netherlands, 2002; 708p.

39. Ogino, A.; Osada, T.; Takada, R.; Takagi, T.; Tsujimoto, S.; Tonoue, T.; Matsui, D.; Katsumata, M.; Yamashita, T.; Tanaka, Y. Life cycle assessment of japanese pig farming using low-protein diet supplemented with amino acids. J. Soil Sci. Plant Nutr. 2013, 59, 107-118. [CrossRef] 